\title{
EVALUASI KINERJA HALTE BUS DENGAN METODE SERVQUAL (STUDI KASUS HALTE TRANS JOGJA TRAYEK 1A, 1B, 2A, DAN 2B)
}

\author{
Muhammad Nur Baskoro Adi ${ }^{1, *}$, Sigit Priyanto ${ }^{2}$, Siti Malkhamah ${ }^{3}$ \\ ${ }^{1, *)}$ Departmen Teknik Sipil dan Lingkungan, Universitas Gadjah Mada, Yogyakarta \\ Email: nurbaskoro19@gmail.com \\ ${ }^{2}$ Departmen Teknik Sipil dan Lingkungan, Universitas Gadjah Mada, Yogyakarta \\ Email: spriyanto2007@ugm.ac.id \\ ${ }^{3}$ Departmen Teknik Sipil dan Lingkungan, Universitas Gadjah Mada, Yogyakarta \\ Email:malkhamah@ugm.ac.id
}

\begin{abstract}
In 2008, the city of Yogyakarta adopted a buy the service scheme in Trans Jogja public transport, aiming to improve the quality of public transport and reduce congestion. Based on the study of GIZ-SUTIP in 2012, there were several problems in Trans Jogja, including insufficient bus stops and excessive staff numbers. The study aimed to evaluate and improve bus stops performance and analyze bus stop service quality according to passenger perceptions. This study is a descriptive study using purposive sampling technique, conducted on 12 Trans Jogja bus stops and 180 respondents. The data obtained were analyzed using MS Excel and SPSS 22 computer program. The results showed that bus stop performance was not good at headways, waiting times, and on-time performance. The clearance time offar-side bus stops was shortened than near-side, and mid-block bus stops. Passengers on foot accessed the near-side and far-side bus stops. The service quality of the Trans Jogja shelter does not match the expectations of the passengers with a Gap Servqual value of -0.790. The service attribute was in quadrant $C$ of the Cartesian Diagram, which requires corrective action from the Trans Jogja operator.
\end{abstract}

Keywords: Bus stops performance, Trans Jogja, Servqual

\section{PENDAHULUAN}

\section{Latar Belakang}

Urbanisasi dan ketersediaan lapangan pekerjaan mengakibatkan pesatnya pertumbuhan penduduk di perkotaan. Pergerakan urbanisasi yang tidak terkendali akan menyebabkan permasalahan seperti fenomena urban sprawl, sementara itu peningkatan kepemilikan kendaraan pribadi yang tidak terkendali akan mengakibatkan kemacetan serta penurunan kualitas lingkungan hidup. Strategi khusus diperlukan untuk mengendalikan laju urbanisasi yaitu dengan menghindari konsentrasi penduduk pada suatu wilayah, memperkuat layanan publik melalui peningkatan peran angkutan umum yang dikelola, dioptimalkan dan diselaraskan dengan infrastruktur moda angkutan umum lainnya.

Salah satu strategi yang diterapkan pemerintah Kota Yogyakarta pada tahun 2008 adalah dengan mengadopsi skema buy the service dengan layanan yang disebut Sistem Transit pada moda transportasi Trans Jogja. Seiring dengan bertambahnya umur layanan dan perluasan jaringan trayek yang mencapai 17 trayek Trans Jogja di tahun 2018, peningkatan akan kualitas pelayanan perlu ditingkatkan. Kualitas pelayanan dapat dinilai melalui aspek pelayanan di atas bus dan pelayanan di luar bus. Untuk layanan di luar bus, keberadaan halte dengan sarana penunjang yang baik akan meningkatkan pengalaman perjalanan 
yang berkesan bagi penumpang Trans Jogja.

Berdasarkan kajian SUTIP (2012) terhadap kinerja Trans Jogja ditemukan beberapa kekurangan dalam struktur kontrak Trans Jogja, salah satunya terdapat inefisiensi jumlah pegawai yang bertugas di setiap halte sebanyak 7 orang petugas DISHUB. Menindaklanjuti hasil kajian SUTIP maka sistem pembayaran elektronik mulai digulirkan pada moda Transportasi Trans Jogja, pemangkasan jumlah pegawai maupun peniadaan pegawai yang bertugas di dalam halte mulai diimplementasikan dilapangan. Namun kebijakan baru ini masih meninggalkan sejumlah permasalahan yang perlu diatasi, seperti ketidak tersediaan petugas di dalam halte membuat penumpang enggan menggunakan halte Trans Jogja karena minimnya informasi dan jaminan keamanan di dalam halte. Dalam penelitian ini dilakukan evaluasi terkait kinerja halte Trans Jogja dari aspek teknis dan pelayanan berdasarkan tipe halte near side, mid block, dan far side.

\section{Tinjauan Pustaka}

Penelitian Adi (2016) terhadap Trans Jogja trayek 1A didapati kinerja Trans Jogja sudah memenuhi standar dengan waktu siklus selama 136,07 menit dan faktor muat sebesar $66,56 \%$, dari hasil penelitian ini dapat dilihat bahwa Trans Jogja trayek 1A merupakan trayek yang potensial.

Kajian terhadap faktor fisik dan perlunya penambahan halte Trans Jogja oleh Supriyanto (2018) didapati jarak halte Trans Jogja dilapangan belum sesuai dengan standar yang ditentukan oleh Direktorat Jenderal Perhubungan Darat tahun 1996 dimana beberapa kecamatan memerlukan penambahan halte dengan angka tarikan dan bangkitan terendah terletak pada daerah pemukiman. Faktor keamanan dan kenyamanan menjadi alasan mayoritas penumpang meng- hendaki perubahan halte portable menjadi halte permanen.

Pengaruh halte Trans Jogja terhadap kecepatan kendaraan dan kinerja jalan yang diteliti oleh Aritonang (2016) pada halte Supeno 2 diketahui keberadaan bus Trans Jogja pada ruas jalan Supeno tidak memengaruhi kinerja jalan dengan nilai derajat kejenuhan sebesar 0,58. Pengaruh halte Trans Jogja terhadap kecepatan pada lajur luar rerata kecepatan kendaraan ketika ada Trans Jogja lebih rendah dibanding ketika tidak ada Trans Jogja, sementara pada lajur dalam rerata kecepatan pada saat ada Trans Jogja belum tentu lebih rendah dibandingkan saat tidak ada Trans Jogja. Keberadaan halte berpengaruh terhadap rerata kecepatan kendaraan sebelum melewati halte Trans Jogja lebih tinggi dibandingkan setelah melewati halte Trans Jogja.

Keberagaman pola dan faktor pengaruh penumpang dalam mengakses halte Trans Jogja oleh Susilowati (2016) pada halte dalam kota dan halte luar kota didapati bahwa pada pola pergerakan penumpang pada halte dalam kota terbatas untuk diakses penumpang dengan diantar dan berjalan kaki, sementara halte luar kota lebih bervariasi dengan diantar, berjalan kaki, sepeda motor, dan angkutan umum. Sementara itu, faktor yang mempengaruhi pola pergerakan halte dalam kota dengan halte luar kota sama, hanya pada halte luar kota ditambah dengan faktor angkutan umum yang beroperasi.

Penelitian terhadap pelayanan Trans Jogja menurut persepsi operator yang dilakukan Syukri (2014) didapati indikator tarif, lampu penerangan, dan pembayaran tiket memiliki kinerja yang baik, namun tidak dengan indikator ketepatan kedatangan/ keberangkatan bus dan luasan halte. Penilaian terhadap luasan halte yang rendah $(1,87)$ membuat penilain terhadap aspek kenyamanan juga rendah $(2,23)$. 
Saragih (2015) dalam penelitiannya terkait kualitas pelayanan Trans Jogja dengan pendekatan Servqual dan Kano didapati secara keseluruhan kinerja Trans Jogja masih rendah dan pelanggan belum puas dengan pelayanan yang ada. Hal tersebut nampak pada 19 item yang memiliki skor kesenjangan negatif pada atribut Customer Requirement yang mana skor kesenjangan secara online lebih tinggi dibandingkan skor kesenjangan secara onboard dengan nilai harapan yang relatif mirip, namun persepsi secara online lebih rendah daripada onboard, maka untuk meningkatkan kinerja pelayanan Trans Jogja diusulkan enam Technical Requirement sebagai rencana aksi.

\section{Sistem Bus Rapid Transit}

Bus Rapid Transit menurut ITDP (2016) merupakan sistem transportasi berbasis bus yang berkapasitas dan berkecepatan tinggi, serta memiliki kualitas layanan yang baik dengan biaya yang relatif murah.

\section{Sistem Transit}

Sistem Transit menurut GIZ-SUTIP (2014) adalah sistem pelayanan angkutan umum massal yang meniru pelayanan BRT, namun tanpa didukung dengan lajur khusus, sehingga kecepatannya rendah karena berada pada lalu lintas campuran.

\section{Sistem Buy the Service}

Menurut Heru Sutomo yang dikutip oleh GIZ-SUTIP (2015), Buy the Service adalah sistem yang dapat diberlakukan untuk mengoperasikan bus dengan spesifikasi pelayanan, baik ditinjau dari sisi kuantitas maupun kualitas dimana pemerintah akan membayar operator berdasarkan tarif atas pelayanan yang mereka laksanakan dan sesuai dengan kilometer yang mereka tempuh.

\section{Halte}

Halte menurut Permenhub (2012) adalah tempat pemberhentian kendaraan bermotor umum untuk menaikkan dan menurunkan penumpang. Menurut Vuchic (1981) sebagaimana terlihat pada Gambar 1, lokasi tempat pemberhentian angkutan umum di jalan diklasifikasikan sebagai berikut ini.

1. Near side, pada persimpangan jalan sebelum memotong jalan simpang.

2. Mid block, pada tempat yang cukup jauh dari persimpangan.

3. Far side, pada persimpangan jalan setelah melewati jalan simpang.

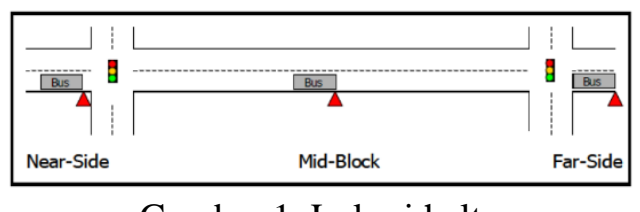

Gambar 1. Lokasi halte

\section{Pelayanan Halte}

TRB (2003) mendefinisikan pelayanan sebagai keseluruhan kinerja layanan transit yang dapat diukur atau dirasakan dari sudut pandang penumpang.

Standar Pelayanan Minumum (SPM) adalah baku mutu pelayanan yang harus dicapai oleh operator dalam memberikan jasa pelayanan kepada pengguna jasa. Beberapa indikator pelayanan pada halte menurut Standar Pelayanan Minimum Angkutan Massal Berbasis Jalan dapat dilihat pada Tabel 1.

\section{Waktu Operasional}

APTA (2010) mendefinisikan waktu operasional sebagai waktu yang dibutuhkan operator transit untuk menyediakan pelayanan termasuk jumlah jam pelayanan dalam sehari dan hari pelayanan dalam seminggu. Tabel 2 menunjukkan Level of Service dari headway dan frekuensi layanan. 
Tabel 1. Indikator pelayanan halte

\begin{tabular}{|c|c|c|c|}
\hline No & Jenis Pelayanan & Indikator & Ukuran \\
\hline 1 & Luas lantai per orang & Ukuran luasan & $\begin{array}{l}4 \mathrm{org} / \mathrm{m}^{2} \text { (puncak) } \\
2 \mathrm{org} / \mathrm{m}^{2} \text { (non puncak) }\end{array}$ \\
\hline 2 & $\begin{array}{l}\text { Fasilitas Kemudahan naik/turun } \\
\text { penumpang }\end{array}$ & $\begin{array}{l}\text { Tinggi lantai halte } \\
\text { sama dengan } \\
\text { lantai bus }\end{array}$ & Tidak ada perbedaan tinggi \\
\hline 3 & $\begin{array}{l}\text { Ketersediaan integrasi jaringan } \\
\text { trayek pengumpan }\end{array}$ & Ketersediaan & Harus tersedia \\
\hline 4 & Waktu tunggu & Waktu (menit) & $\begin{array}{l}\text { Maksimal } 7 \text { menit (puncak) } \\
\text { Maksimal } 15 \text { menit (non puncak) }\end{array}$ \\
\hline 5 & Waktu berhenti di halte & Waktu (detik) & $\begin{array}{l}\text { Maksimal } 45 \text { detik (puncak) } \\
\text { Maksimal } 60 \text { detik (non puncak) }\end{array}$ \\
\hline 6 & Informasi pelayanan & $\begin{array}{l}\text { a. Bentuk } \\
\text { b. Tempat } \\
\text { c. Kondisi }\end{array}$ & $\begin{array}{l}\text { a. Berupa papan informasi, visual audio, dan tulisan } \\
\text { b. Penempatan mudah terbaca dan jelas terlihat } \\
\text { c. Kondisi baik dan/atau berfungsi } \\
\text { d. Dapat melalui media internet }\end{array}$ \\
\hline 7 & Akses keluar masuk halte & $\begin{array}{l}\text { Terdapat ruang } \\
\text { yang cukup untuk } \\
\text { akses }\end{array}$ & Sesuai dengan standar teknis \\
\hline 8 & Sistem pembayaran & $\begin{array}{lr}\text { Bukti } & \text { pembelian } \\
\text { tiket } & \text { untuk } \\
\text { petugas } & \text { dan } \\
\text { penumpang } & \end{array}$ & $\begin{array}{l}\text { a. Smart card (Full BRT) } \\
\text { b. Manual dan/atau Smart card (Sistem transit) } \\
\text { c. Perangkat atau mesin pengecekan Smart card } \\
\text { (tap) }\end{array}$ \\
\hline
\end{tabular}

Tabel 2. LOS frekuensi pelayanan

\begin{tabular}{cccl}
\hline LOS & Avg. Headway (min) & Veh/h & \multicolumn{1}{c}{ Comments } \\
\hline A & $<10$ & $>6$ & Passengers do not need schedules \\
\hline B & $10-14$ & $5-6$ & Frequent service, passengers consult schedules \\
\hline C & $15-20$ & $3-4$ & Maximum desirable time to wait if bus/train missed \\
\hline D & $21-30$ & 2 & Service unattractive to choice riders \\
\hline E & $31-60$ & 1 & Service available during the hour \\
\hline F & $>60$ & $<1$ & Service unattractive to all riders \\
\hline
\end{tabular}

Tabel 3. LOS ketepatan waktu

\begin{tabular}{ccl}
\hline LOS & On-Time Percentage & Comments \\
\hline A & $95,0-100,0 \%$ & 1 late transit vehicle every 2 weeks (no transfer) \\
\hline B & $90,0-94,9 \%$ & 1 late transit vehicle every week (no transfer) \\
\hline C & $85,0-89,9 \%$ & 3 late transit vehicle every 2 weeks (no transfer) \\
\hline D & $80,0-84,9 \%$ & 2 late transit vehicle every week (no transfer) \\
\hline E & $75,0-79,9 \%$ & 1 late transit vehicle every day (with a transfer) \\
\hline F & $<75,0 \%$ & 1 late transit vehicle at least daily (with a transfer) \\
\hline
\end{tabular}

Tabel 4. LOS ruang tunggu penumpang

\begin{tabular}{ccccc}
\hline \multirow{2}{*}{ OS } & \multicolumn{2}{c}{ Average Pedestrian Area } & \multicolumn{2}{c}{ Average Inter - Personal Spacing } \\
\cline { 2 - 5 } & $\left(\mathrm{ft}^{2} / \mathrm{p}\right)$ & $\left(\mathrm{m}^{2} / \mathrm{p}\right)$ & $(\mathrm{ft})$ & $(\mathrm{m})$ \\
\hline $\mathbf{A}$ & $\geq 13$ & $\geq 1,2$ & $\geq 4,0$ & $\geq 1,2$ \\
\hline B & $10-13$ & $0,9-1,2$ & $3,5-4,0$ & $1,1-1,2$ \\
\hline $\mathbf{C}$ & $7-10$ & $0,7-0,9$ & $3,0-3,5$ & $0,9-1,1$ \\
\hline $\mathbf{D}$ & $3-7$ & $0,3-0,7$ & $2,0-3,0$ & $0,6-0,9$ \\
\hline $\mathbf{E}$ & $2-3$ & $0,2-0,3$ & $<2,0$ & $<0,6$ \\
\hline F & $<2$ & $<0,2$ & Variable & Variable \\
\hline
\end{tabular}

\section{Kinerja Tepat Waktu}

TRB (2013). Kinerja tepat waktu adalah ukuran keandalan yang paling banyak digunakan dan dapat diterapkan pada layanan transit yang beroperasi sesuai dengan jadwal yang dipublikasikan. Definisi tepat waktu yang mencermin perspektif penumpang dan operator adalah keberangkatan 1 menit lebih awal hingga 5 menit keterlambatan. Level of Service dari kinerja tepat waktu dapat dilihat pada Tabel 3.

\section{Ruang Tunggu Penumpang}

APTA (2010) dalam merencanakan luasan halte perlu dipertimbangkan kebutuhan area sirkulasi dan ruang tunggu penumpang. 
Level of Service pada ruang tunggu penumpang dapat dilihat pada Tabel 4 .

\section{Service Quality}

TRB (2002). Dalam riset pasar, kepuasan pelanggan atau persepsi kualitas suatu layanan dipandang oleh beberapa peneliti sebagai fungsi dari harapan dan persepsi pelanggan. Harapan adalah prediksi tentang apa yang mungkin terjadi, sementara persepsi mencerminkan kualitas layanan yang dirasakan oleh pelanggan.

\section{Dimensi Kualitas Jasa}

Pasaruman, et. al dalam Jasfar (2005) mengemukakan 5 (lima) dimensi kualitas pelayanan sebagai berikut ini.

1. Kehandalan yaitu kemampuan memberi pelayanan secara akurat kepada pelanggan.

2. Daya tanggap yaitu bentuk tindakan dalam merespon pelanggan secara tepat waktu.

3. Jaminan yaitu kemapuan menumbuhkan kepercayaan dimata pelanggan

4. Empati yaitu perhatian yang diberikan perusahaan terhadap pelanggan..

5. Bukti fisik yaitu segala sesuatu yang mempengaruhi kualitas pelayanan.

\section{Gap Analysis Model}

Jasfar (2005). Gap Analysis Model dikembangkan Parasuraman, dkk dimana kelima dimensi kualitas pelayanan digunakan untuk menjelaskan konsep kesenjangan kualitas jasa yang timbul akibat adanya perbedaan antara harapan konsumen mengenai suatu jasa (expected service quality) dan persepsi terhadap jasa yang ditawarkan (perceived service quality). Skor SERVQUAL dapat dihitung dengan menggunakan rumus sebagaimana Persamaan (1).

SERVQUAL $=$ Persepsi - Harapan

\section{METODE PENELITIAN}

Penelitian dilaksanakan pada 12 halte Trans Jogja pada pelayanan trayek $1 \mathrm{~A}, 1 \mathrm{~B}, 2 \mathrm{~A}$, dan 2B yang berada di dalam ring road yang diklasifikasikan kedalam halte near side, mid block, dan far side. Untuk menganalisis persepsi dan harapan penumpang terhadap pelayanan pada halte Trans Jogja dilakukan menyebaran kuesioner yang meliputi 5 dimensi kualitas terhadap 180 penumpang yang menunggu di halte Trans Jogja.

Populasi penumpang yang menunggu bus Trans Jogja tidak diketahui pasti jumlahnya sehingga dalam penelitian ini penentuan jumlah responden menggunakan Formula Lameshow dengan nilai kepercayaan (Z) $95 \%$, proporsi populasi (p) $50 \%$, dan sampling error (e) $10 \%$ didapati jumlah minimal sampel sebanyak 100 orang.

Jumlah halte yang dipilih disesuaikan dengan tujuan penelitian untuk mengetahui kinerja halte pada layanan Trans Jogja trayek 1A, 1B, 2A, dan 2B berdasarkan letaknya sebelum (near side), diantara (mid block), dan setelah (far side) simpang tanpa bermaksud untuk menggeneralisasikan hasil penelitian pada semua halte Trans Jogja. Penentuan sampel penelitian menggunakan salah satu teknik pada non probability sampling yaitu teknik purposive sampling dimana pemilihan sampel didasarkan pada tujuan yang hendak dicapai pada penelitian ini.

Lokasi penelitian dilakukan di 12 halte Trans Jogja, yaitu Halte berikut:

1. Sudirman 2 (Bumiputera),

2. JL Solo (De Britto),

3. Malioboro 3 (B. Vredeburg),

4. Cik Di Tiro 1,

5. JL Solo (Jogja Bisnis),

6. JL Solo (Ambarukmo),

7. Senopati 2 (Taman Pintar),

8. Gedong Kuning (Banguntapan),

9. Mangkubumi 1 (Tugu),

10. RS. Mata Dr. YAP,

11. Sugiono 1 (SD Pujokusuman),

12. JL Colombo (Samirono).

Data yang digunakan dalam penelitian ini meliputi data primer dan data sekunder. Data primer meliputi lembar observasi dan lembar kuesioner yang dilaksanakan pada 
hari Senin hingga Kamis, sementara data lainnya berupa data sekunder yang diperoleh dari PT. Anindya Mitra Internasional dan PT. Jogja Tugu Trans.

Pengumpulan data dilakukan pada hari kerja dengan tujuan mendapatkan data yang merepresentasikan kinerja halte dan Trans Jogja pada kondisi sehari - hari karena pada hari libur fluktuasi kepadatan lalu lintas dan penumpang Trans Jogja menyebabkan data yang diperoleh tidak normal. Hari-hari kerja dapat mencerminkan tujuan utama Trans Jogja sebagai transportasi publik yang ditujukan untuk mengakomodasi kebutuhan mobilitas penumpang dan menekan penggunaan kendaraan pribadi.

Data yang diperoleh melalui instrumen kuesioner selanjutnya dibuat pengkodean berdasarkan skala Linkert dan di analisis skor persepsi dan harapan penumpang dengan bantuan software Microsoft Excel untuk mendapatkan nilai gap Servqual masing - masing atribut pelayanan pada halte Trans Jogja dan mengetahui atribut pelayanan yang perlu diperbaiki. Hasil analisis selain kuesioner yang diolah dengan bantuan software Ms. Excel, selanjutnya diban-dingkan dengan ketentuan pada Standar Pelayanan Angkutan Umum Massal Berbasis Jalan dan Transit Capacity and Quality of Service Manual.

\section{HASIL DAN PEMBAHASAN}

\section{Tingkat Layanan Waktu Antara}

Tingkat layanan waktu antara pada halte Trans Jogja secara keseluruhan kurang baik. Tingkat layanan terbaik dicatatkan Trans Jogja trayek 1A (LOS A) dengan rerata waktu antara kurang dari 10 menit, sementara tingkat layanan terburuk dicatatkan Trans Jogja trayek 11 (LOS E) dengan waktu antara pada interval 30 menit sampai 60 menit.

Perbedaan waktu antara yang dicatatkan oleh masing-masing trayek Trans Jogja disebabkan oleh besaran waktu siklus di setiap trayek yang berbeda, jumlah armada yang melayani masing-masing trayek, dan kondisi lalu lintas yang dialami masing masing trayek di lapangan.

\section{Tingkat Layanan Ketepatan Bus}

Tingkat layanan ketepatan bus pada halte Trans Jogja secara keseluruhan buruk dengan rerata ketepatan kurang dari $75 \%$, sehingga layanan Trans Jogja kurang dapat diandalkan. Pada penelitian ini bus yang datang tepat waktu merupakan bus yang datang 5 menit lebih awal hingga 10 menit keterlambatan karena merupakan sistem transit. Trayek 2A mencatatkan tingkat ketepatan terendah dibandingkan dengan trayek lainnya.

Perbedaan ketepatan kedatangan bus tiap halte dipengaruhi oleh kondisi lalu lintas yang dilalui oleh trayek Trans Jogja, kondisi dan kualitas pemeliharaan armada Trans Jogja. Bus yang mogok dapat mengurangi kehandalan layanan, keterbatasan staff dan bus cadangan ketika terjadi kondisi darurat, operasional Trans Jogja pada lalu lintas campuran tanpa dilengkapi oleh prioritas bus, dan jumlah halte yang dilayani semakin banyak membuat bus Trans Jogja sering berhenti, sehingga mengurangi ketepatan kedatangan bus di tiap halte.

\section{Tingkat Layanan pada Ruang Tunggu}

Kenyamanan ruang tunggu penumpang dapat diukur dari luasan yang tersedia bagi penumpang ketika menunggu kedatangan bus Trans Jogja di halte. Secara keseluruhan luasan ruang tunggu yang tersedia cukup baik. Di dalam halte tersedia ruangan yang lebih dari $0,25 \mathrm{~m}^{2}$ /orang dan minimal LOS D, namun pada halte Trans Jogja yang memiliki tingkat layanan LOS D memerlukan perbaikan karena pada tingkat layanan ini penumpang masih berdesakan dan sirkulasi penumpang terbatas. Pada halte Malioboro 3 (B. Vredeburg) dengan luasan ruang yang tersedia mampu melayani jumlah permintaan perjalanan yang cukup padat. 
Tingkat layanan ruang tunggu penumpang di setiap halte Trans Jogja bervariasi karena dipengaruhi oleh jumlah penumpang yang memanfaatkan halte untuk naik dan turun. Ketersediaan lahan halte on street cenderung terbatas dibandingkan halte off street, dan waktu tunggu yang lama menyebabkan kebutuhan ruang tunggu semakin besar dan kondisi ini berakibat pada kenyamanan penumpang.

\section{Standar Pelayanan Waktu Tunggu}

Kinerja pelayanan waktu tunggu pada halte Trans Jogja secara keseluruhan masih kurang baik, karena sebagian besar trayek Trans Jogja baik pada saat jam puncak pagi maupun saat jam puncak sore waktu tunggu lebih dari 7 menit yang artinya belum (B) memenuhi standar pemerintah. Trans Jogja trayek 1A dan 2A mencatatkan waktu tunggu yang baik di setiap halte pada saat jam puncak kurang dari 7 menit dan saat jam tidak puncak kurang dari 15 menit. Waktu tunggu yang cukup lama diperlukan penumpang untuk menunggu Trans Jogja Trayek 11.

Perbedaan waktu tunggu yang dicatatkan setiap halte disebabkan oleh waktu antara yang mencerminkan frekuensi layanan. Semakin besar frekuensi layanan, maka waktu tunggu semakin singkat, tingkat keterisian bus yang penuh menyebabkan penumpang harus menunggu kedatangan bus berikutnya. Pola kedatangan penumpang pada halte, semakin dekat waktu kedatangan penumpang di halte yang lebih dekat dengan waktu kedatangan bus akan membuat waktu tunggu semakin singkat, dan waktu muat pada halte sebelumnya. Selain itu, semakin lama waktu muat pada halte sebelumnya berpengaruh pada waktu tunggu halte setelahnya.

\section{Standar Pelayanan Waktu Muat}

Pelayanan waktu muat pada halte Trans Jogja secara keseluruhan baik dimana waktu yang dibutuhkan bus Trans Jogja untuk memuat penumpang saat jam puncak kurang dari 45 detik dan kurang dari 60 detik saat jam tidak puncak. Dari waktu muat ini diketahui bahwa halte Malioboro 3 (B. Vredeburg) merupakan halte dengan waktu muat terbaik, sementara Trans Jogja trayek 1A, 2A, 3A,08, dan 10 merupakan trayek dengan jumlah permintaan perjalanan terbanyak dengan besarnya waktu muat yang dicatatkan di tiap halte.

Perbedaan waktu muat yang dicatatkan tersebut dipengaruhi oleh permintaan perjalanan penumpang yang naik dan turun. Semakin banyak penumpang yang naik maupun turun pada halte, maka waktu muat akan semakin lama. Selain itu, jarak halte yang berjauhan akan membuat penumpang menumpuk di satu halte, sehingga waktu muat penumpang pada halte akan semakin lama. Metode pembayaran di atas bus lebih lama terutama bagi yang tidak memiliki smartcard dan penumpang yang melakukan single trip, tipe dan ukuran bus Trans Jogja yang kecil berpotensi pada lamanya waktu muat karena penumpang harus bergantian karena hanya terdapat satu pintu untuk sirkulasi keluar masuk bus. Namun, semakin terampil pengemudi dalam meminimalisasi jarak bus dengan halte waktu muat yang diperlukan semakin singkat, dan sirkulasi di dalam bus Trans Jogja apalagi jika penumpang diijinkan untuk berdiri turut berpengaruh terhadap waktu muat penumpang.

\section{Waktu Pengosongan Halte}

Waktu pengosongan yang dicatatkan bus Trans Jogja pada setiap halte adalah sejauh 5 meter, sehingga hal tersebut sudah dapat dikatakan dalam kategori baik. Terkait dengan lokasi halte, halte far side (halte yang berada setelah simpang) memliki waktu pengosongan yang lebih baik dibandingkan tipe mid block dan near side, baik pada waktu puncak maupun non puncak. Rata-rata waktu pengosongan halte far side lebih cepat 4 detik saat jam puncak pagi dan lebih cepat 4 detik saat jam tidak puncak.

Perbedaan waktu pengosongan pada masing - masing halte dipengaruhi oleh volume lalu lintas, dikarenakan waktu yang 
dibutuhkan bus akan semakin lama seiring dengan meningkatnya volume lalu lintas. Letak halte juga berpengaruh terhadap waktu pengosongan. Pada halte far side tidak ada konflik dengan lalu lintas belok kiri, dan juga masih minim hambatan samping. Selain itu, pemahaman pengendara terhadap rambu yield-to-bus pada bus Trans Jogja yang rendah juga menjadi faktor penyebab waktu pengosongan lebih lama.

\section{Karakteristik Pengguna Halte}

Pada penelitian ini diperoleh hasil bahwa mayoritas sebesar $58 \%$ adalah perempuan, $36 \%$ pelajar/mahasiswa/i, $36 \%$ belum berpenghasilan, dan $39 \%$ tujuan perjalanan lain-lain. Hasil ini menunjukkan bahwa tarif Trans Jogja cukup ramah bagi pelajar/mahasiswa/i namun belum mampu diandalkan penumpang karena sebagian besar mengandalkan layanan ini untuk pulang setelah berkegiatan.

Gambar 2 menunjukkan perbedaan dalam cara penumpang mencapai halte, yang mana pada halte near side dan far side mayoritas penumpang dapat menempuhnya dengan berjalan kaki, sementara pada halte mid block penumpang mengaksesnya dengan angkutan umum.

\section{Kesenjangan Layanan Halte}

Perbedaan persepsi penumpang akan pelayanan yang seharusnya mereka terima menimbulkan kesenjangan yang dapat dilihat pada Gambar 3. Berdasarkan persepsi penumpang terhadap kualitas pelayanan pada halte Trans Jogja didapati pelayanan yang diterima penumpang lebih rendah daripada yang mereka harapkan, sehingga penumpang mempersepsikan kualitas pelayanan negatif $(-0,790)$. Berdasarkan analisis item-by-item, atribut ketepatan kedatangan bus di halte memiliki kesenjangan yang cukup besar $(-1,583)$, diikuti atribut ketepatan waktu tunggu bus $(-1,556)$. Berdasarkan analisis dimensionby-dimension, dimensi kehandalan memiliki kesenjangan yang cukup besar $(-1,013)$, diikuti oleh dimensi bukti fisik $(-0,964)$.

Untuk lebih memudahkan operator Trans Jogja dalam menentukan prioritas kinerja layanan yang perlu ditingkatkan, maka kualitas layanan yang dinilai oleh penumpang dipetakan kedalam Diagram Kartesius (Gambar 4 dan Tabel 5). Atribut layanan yang berada pada kuadarn B perlu dipertahankan, sementara atribut layanan pada kuadran $\mathrm{C}$ perlu ditingkatkan pelayanannya.

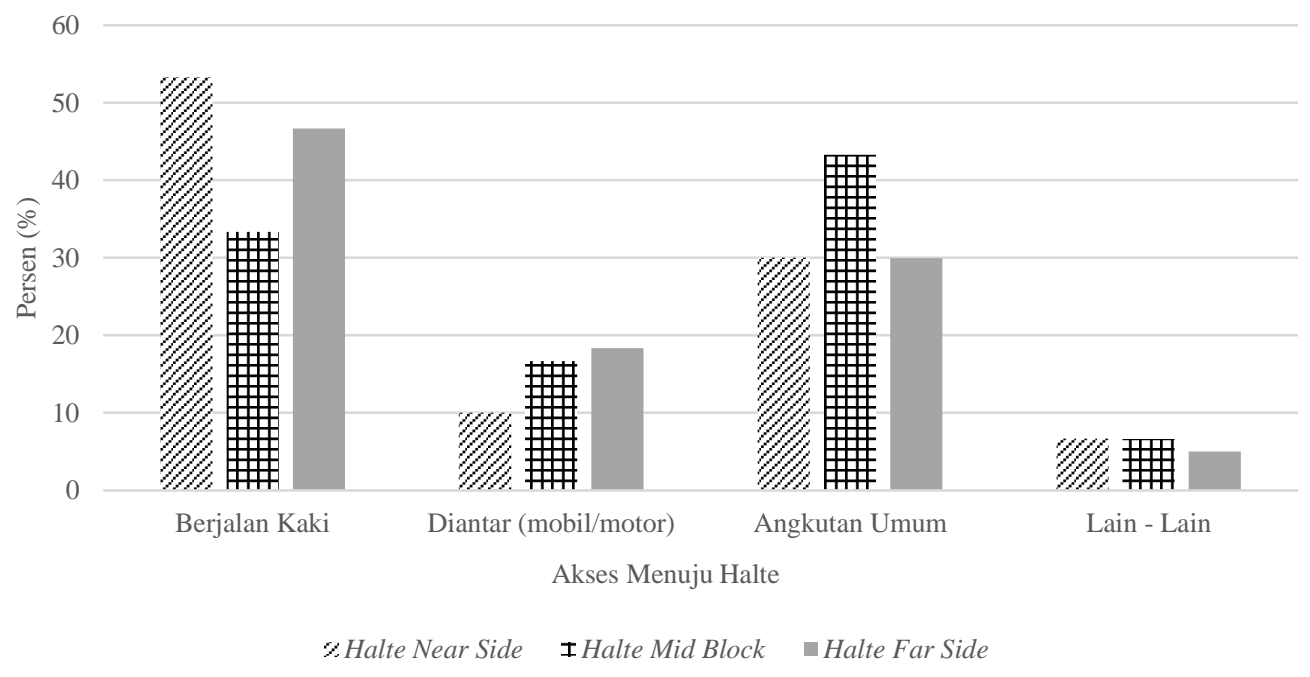

Gambar 2. Akses halte 
๑Persepsi ÐHarapan

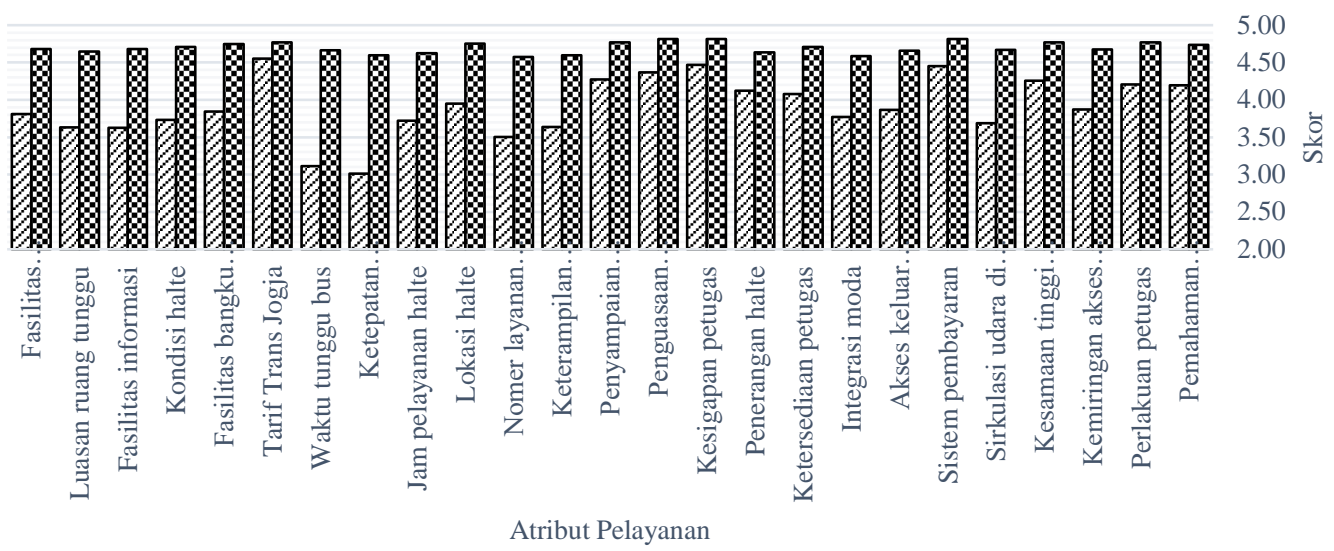

Gambar 3. Persepsi dan harapan penumpang

Tabel 5. Persepsi pelayanan penumpang

\begin{tabular}{|c|c|c|c|c|c|}
\hline Prioritas & Atribut & $\begin{array}{c}\text { No } \\
\text { Atribut }\end{array}$ & Gap Score & Dimensi & Kuadran \\
\hline 1 & Ketepatan kedatangan bus & 8 & $-1,583$ & Kehandalan & $\mathrm{C}$ \\
\hline 2 & Waktu tunggu bus & 7 & $-1,556$ & Kehandalan & $\mathrm{C}$ \\
\hline 3 & Nomer layanan dan pengaduan & 11 & $-1,067$ & Daya Tanggap & $\mathrm{C}$ \\
\hline 4 & Fasilitas informasi & 3 & $-1,056$ & Bukti Fisik & $\mathrm{C}$ \\
\hline 5 & Luasan ruang tunggu & 2 & $-1,011$ & Bukti Fisik & $\mathrm{C}$ \\
\hline 6 & Sirkulasi halte & 20 & $-0,983$ & Empati & $\mathrm{C}$ \\
\hline 7 & Kondisi halte & 4 & $-0,978$ & Bukti Fisisk & $\mathrm{D}$ \\
\hline 8 & Keterampilan pegemudi bus & 12 & $-0,956$ & Daya Tanggap & $\mathrm{C}$ \\
\hline 9 & Fasilitas bangku dan shelter & 5 & $-0,906$ & Bukti Fisik & $\mathrm{D}$ \\
\hline 10 & Jam pelayanan halte & 9 & $-0,900$ & Kehandalan & $\mathrm{C}$ \\
\hline 11 & Fasilitas kebersihan & 1 & $-0,872$ & Bukti Fisik & $\mathrm{C}$ \\
\hline 12 & Integrasi moda & 18 & $-0,811$ & Jaminan & $\mathrm{C}$ \\
\hline 13 & Lokasi halte & 10 & $-0,806$ & Kehandalan & $\mathrm{B}$ \\
\hline 14 & Kemiringan akses halte & 22 & $-0,806$ & Empati & $\mathrm{C}$ \\
\hline 15 & Akses keluar masuk halte & 18 & $-0,794$ & Jaminan & $\mathrm{C}$ \\
\hline 16 & Ketersediaan petugas & 17 & $-0,633$ & Jaminan & B \\
\hline 17 & Perlakuan petugas & 23 & $-0,567$ & Empati & B \\
\hline 18 & $\begin{array}{l}\text { Pemahaman } \\
\text { penumpang }\end{array}$ & 24 & $-0,544$ & Empati & B \\
\hline 19 & Kesamaan tinggi lantai halte & 21 & $-0,517$ & Empati & $\mathrm{B}$ \\
\hline 20 & Peneranngan halte & 16 & $-0,511$ & Jaminan & A \\
\hline 21 & Penyampaian informasi & 13 & $-0,500$ & Daya Tanggap & $\mathrm{B}$ \\
\hline 22 & Penguasaan informasi & 14 & $-0,450$ & Daya Tanggap & B \\
\hline 23 & Sistem pembayaran & 19 & $-0,367$ & Jaminan & $\mathrm{B}$ \\
\hline 24 & Kesigapan petugas & 15 & $-0,350$ & Daya Tanggap & $\mathrm{B}$ \\
\hline 25 & Tarif Trans Jogja & 6 & $-0,222$ & Kehandalan & $\mathrm{B}$ \\
\hline
\end{tabular}




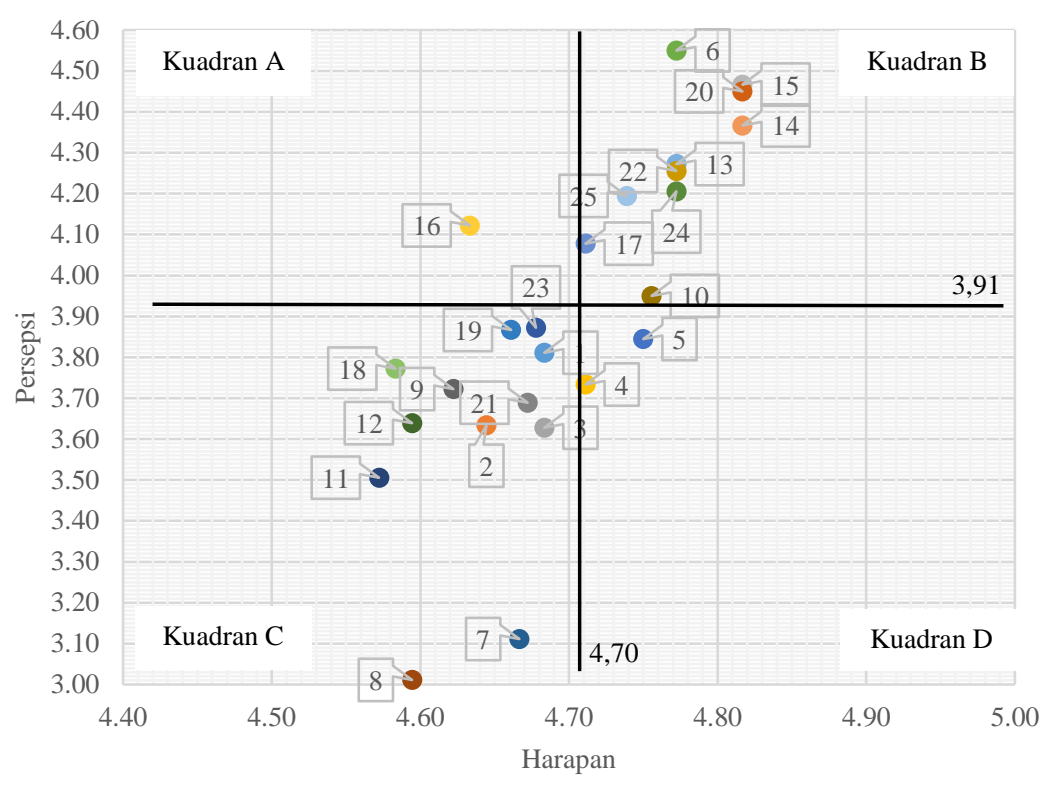

Gambar 4. Diagram kartesius

\section{KESIMPULAN}

1. Kinerja pelayanan pada halte Trans Jogja masih kurang baik, disebabkan oleh ketepatan waktu kedatangan Trans Jogja masih rendah, beberapa ruang tunggu halte berada pada LOS D, pada sebagian besar trayek Trans Jogja waktu tunggu masih lama dan pada beberapa trayek Trans Jogja frekuensi layanan masih rendah. Kinerja pelayanan yang baik ditunjukkan oleh waktu muat yang memenuhi standar dan waktu pengosongan yang singkat. Pada halte near side dan far side penumpang nyaman mengakses halte dengan berjalan kaki.

2. Menurut persepsi penumpang seluruh atribut pelayanan pada halte Trans Jogja masih kurang sesuai dengan harapan penumpang dengan nilai Gap Servqual sebesar -0,790. Berdasarkan analisis item-by-item atribut ketepatan kedatangan bus masih kurang $(-1,583)$ dan waktu tunggu masih lama $(-1,556)$. Sementara berdasarkan analisis dimensions-by-dimensions, dimensi kehandalan $(-1,013)$ dan bukti fisik ($0,964)$ masih kurang. Pemetaan nilai persepsi dan harapan penumpang pada
Diagram Kartesius diketahui bahwa atribut pelayanan pada kuadran $\mathrm{C}$ memerlukan tindakan perbaikan oleh operator Trans Jogja

\section{DAFTAR PUSTAKA}

Adi, M. N. B. (2016). "Evaluasi Kinerja Halte Trans Jogja Trayek 1A: Studi Kasus Halte Prambanan, Sudirman 1, dan Malioboro 1". Tugas Akhir. Universitas Islam Indonesia. Yogyakarta: Tidak dipublikasikan

American Public Transportation Association. (2010). "APTA Standart Development Program Recommended Practice". APTA Bus Rapid Transit Working Group, Washington.

Aritonang, A. H. (2015). "Pengaruh Halte Trans Jogja terhadap Kecepatan Kendaraan Lain dan Kinerja Jalan (Studi Kasus: Halte Senopati 2, Jalan Senopati, Yogyakarta)". Tugas Akhir. Universitas Gadjah Mada. Yogyakarta

GIZ-SUTIP. (2014). "Pedoman Perencanaan Mobilitas Perkotaan di Indonesia". Kementrian PPN/Bappenas, Jakarta. 
GIZ-SUTIP. (2015). "Langkah Jitu Pembenahan Angkutan Perkotaan". Kementrian PPN/Bappenas, Jakarta.

Institute for Transportation \& Development Policy. (2016). "The BRT Standard". Institute for Transportation \& Development Policy

Jasfar, F. (2005). "Manajemen Jasa Pendekatan Terpadu”. Ghalia Indonesia. Bogor

Permenhub Republik Indonesia. (2012). "Standar Pelayanan Minimal Angkutan Massal Berbasis Jalan”. Menteri Perhubungan Republik Indonesia. Jakarta.

Saragih, R. U. (2015). "Analysis Service Quality of Trans Jogja with Approach of Integration of Servqual and Kano's Model into Quality Function Deployment (QFD)". Tesis. Universitas Gadjah Mada. Yogyakarta

Supriyanto, M. S. (2018). "Kajian Faktor Fisik dan Perlunya Penambahan Halte Bus Trans Jogja di Kota Yogyakarta dan Sekitarnya". Tugas Akhir. Universitas Gadjah Mada, Yogyakarta
Susilowati, N. R. (2016). "Keberagaman Pola Pergerakan Penumpang dalam Mengakses Halte Trans Jogja". Tesis. Universitas Gadjah Mada. Yogyakarta

Syukri, R. (2014). "Evaluasi Kinerja Pelayanan Angkutan Umum Trans Jogja berdasarkan Persepsi Operator". Tugas Akhir. Universitas Gadjah Mada. Yogyakarta

Transportation Research Board. (2002). " $A$ Guidebook for Developing a Transit Performance-Measurement System". Transit Cooperative Research Program. Washington D.C.

Transportation Research Board. (2003). "2nd Edition the Transit Capacity and Quality Service Manual”. Transit Cooperative Research Program. Washington D.C.

Transportation Research Board. (2013). "3rd Edition the Transit Capacity and Quality Service Manual”. Transit Cooperative Research Program. Washington D.C.

Vuchan, V. R. (1981). "Urban Public Transport: System and Technology". New Jersey: Prentice-Hall. 